\title{
Agen Diabetagonik Streptozotocin untuk Membuat Tikus Putih Jantan Diabetes Mellitus
}

\author{
(DIABETAGONIK AGENT STREPTOZOCIN TO MAKE \\ WHITE RATS MALE DIABETES MELLITUS)
}

\author{
Nengah Tegar Saputra ${ }^{1 *}$, I Nyoman Suartha ${ }^{2}$, Anak Agung Gde Oka Dharmayudha ${ }^{3}$ \\ ${ }^{1}$ Divisi Kapal Ternak, Dirjen Perhubungan, Kementerian Perhubungan, \\ J1. Jendral A. Yani No. 52 Cempaka Putih Jakarta Pusat. \\ ${ }^{2}$ Laboratorium Diagnosa Klinik Veteriner Fakultas Kedokteran Hewan, Universitas Udayana, \\ Denpasar, Bali. ${ }^{3}$ Laboratorium Bedah dan Radiologi Veteriner Fakultas Kedokteran Hewan, \\ Universitas Udayana, Denpasar Bali \\ *Email: tsyaputraa@yahoo.com
}

\begin{abstract}
ABSTRAK
Penyakit metabolik seperti diabetes mellitus cenderung meningkat, dengan angka kejadian dan kematian yang tinggi. Penelitian mengenai diabetes mellitus dengan penggunaan hewan model tikus sangat banyak. Agen diabetagonik eksprimental yang digunakan ada aloksan dan streptozocin (STZ). Efek samping penggunaan STZ dilaporkan lebih rendah dibandingkan aloksan. Tujuan penelitian ini untuk melihat respon tikus putih (Rattus norvegicus) jantan terhadap induksi agen streptozotocin sehingga membuat tikus dalam kondisi diabetes mellitus eksperimental. Injeksi agen streptozotocin dilakukan secara intra peritoneum dengan dosis $45 \mathrm{mg} / \mathrm{kg}$ BB. Sebelum diinduksi dengan STZ tikus dipuasakan dan diukur kadar glukosa darah. Kadar glukosa darah tikus harus dalam kisaran normal. Tikus putih yang digunakan sebanyak 88 ekor. Pengukuran kadar glukosa darah tikus dilakukan hari ke3 pasca injeksi STZ. Hasil penelitian menunjukkan bahwa tikus putih memberikan respon peningkatan glukosa darah sebagai indikasi diabetes mellitus ekperimental. Tikus putih yang mengalami hiperglikemia sebanyak 54,8\% dengan rincian $21,5 \%$ ringan, $11,8 \%$ sedang dan $21,5 \%$ berat. Hasil ini menunjukkan bahwa agen Streptozotocin sangat tepat digunakan untuk membuat hewan coba tikus dalam kondisi diabetes mellitus eksperimental.
\end{abstract}

Kata kunci: streptozotocin; hiperglikemia; diabetes mellitus; tikus putih jantan

\section{ABSTRACT}

Trend of metabolic diseases like diabetes mellitus were growth up, with morbility and mortality rate are higher. Most of research about diabetes mellitus are used to rat. Experimental diabetagonic agent was use like aloksan and streptozocin (STZ). The side effect of STZ are less than aloksan. The purpose of this study was to see the response of white rats (Rattus norvegicus) male against streptozotocin agent to make the rats in the experimental conditions of diabetes mellitus. Injection of streptozotocin agent carried by intra peritoneal with dose of $45 \mathrm{mg} / \mathrm{kg}$. White rats have sarver before induction STZ. Level of blood glucose are measure before induction STZ (day 0) and third day after induction STZ. The number of rats is 88 individuals. The results showed that rats provide a response to the increase in blood glucose as an indication of experimental diabetes mellitus which is indicated by a percentage value. White rats experiencing hyperglycemia as much as 54,8\% with the details of $21.5 \%$ mild, $11.8 \%$ moderate and $21.5 \%$ by weight . These results indicate that a very precise Streptozotocin agent used to make experimental animals in the experimental conditions of diabetes mellitus.

Keywords: streptozotocin; hyperglycemia; diabetes mellitus; male white rats

\section{PENDAHULUAN}

Diabetes mellitus (DM) yang juga dikenal sebagai non-communicable disease merupakan salah satu penyakit sistemik yang paling memprihatinkan di Indonesia.
Hal ini dikarenakan penyakit DM memiliki angka kejadian dan kematian yang cukup tinggi. Diabetes mellitus suatu kondisi konsentrasi glukosa dalam darah secara kronis lebih tinggi (hiperglikemia) dari pada 
nilai normal akibat tubuh kekurangan insulin atau fungsi insulin tidak efektif.

Setengah dari jumlah kasus diabetes mellitus tidak terdiagnosis karena pada umumnya diabetes tidak disertai gejala sampai terjadinya komplikasi. Penyakit diabetes mellitus semakin hari semakin meningkat dan hal ini dapat dilihat dari meningkatnya frekuensi kejadian penyakit tersebut di masyarakat. Diperkirakan 194 juta jiwa atau $5,1 \%$ dari 3,8 milyar penduduk dunia yang berusia 20-79 tahun menderita diabetes mellitus. Jumlah penderita diabetes mellitus di Indonesia jumlahnya sangat besar. Pada tahun 2000 jumlah penderita diabetes mellitus telah mencapai 8,4 juta jiwa, pada tahun 2003 jumlah penderita 13.797 .470 jiwa sedangkan pada tahun 2005 jumlahnya telah mencapai sekitar 24 juta orang (World Health Organization, 2003).

Diabetes mellitus dapat dikatagorikan dalam tiga tipe. Diabetes tipe 1 adalah kondisi diabetes karena kekurangan insulin akibat ketidak mampuan tubuh memproduksi insulin. Diabetes mellitus tipe 2 merupakan kumpulan gejala yang timbul oleh adanya peningkatan kadar glukosa darah akibat kekurangan insulin baik absolut maupun relatif (Suyono, 2005). Diabetes tipe 3 kondisi yang sering teramati pada saat wanita hamil. Setelah melahirkan kadar glukosa darah kembali dalam kisaran normal.

Percobaan penelitian mengenai DM dengan menggunakan hewan model didasarkan pada patogenesis penyakit tersebut pada manusia yang bersifat kronis atau berlangsung menahun. Pada saat ini telah dilakukan penelitian menggunakan hewan model yang secara patologis dibuat menderita DM. Kondisi patologis pada hewan model dibuat untuk melakukan pencegahan, mengetahui patogenesis penyakit, menetapkan diagnosis, dan terapi yang digunakan dalam penanganan penyakit DM. Meskipun demikian, kondisi patologis hewan model tersebut tidak sepenuhnya menggambarkan kondisi patologis secara nyata pada manusia (Alwan, 1994).

Pada hewan model, DM sering disebabkan akibat pemberian aloksan maupun streptozotocin (STZ) yang dapat mengakibatkan kerusakan pada sel beta langerhans pankreas (Yuliantika et al., 2013). Aloksan adalah senyawa kimia yang digunakan untuk menginduksi diabetes pada binatang percobaan. Aloksan merupakan senyawa hidrofilik yang tidak stabil dan toksik selektif terhadap hati dan ginjal, tetapi dalam dosis tertentu menyebabkan destruktif selektif pada sel beta pankreas. Aloksan murni diperoleh dari oksidasi asam urat oleh asam nitrat. Waktu paruh aloksan pada $\mathrm{pH}$ 7,4 dan suhu $37^{0} \mathrm{C}$ adalah 1,5 menit dan sangat mudah teroksidasi (Yuda, 2013).

Berbeda halnya dengan aloksan, senyawa streptozozin memiliki waktu paruh yang cukup lama dan tidak mudah teroksidasi. Streptozotocin bekerja dengan cara membentuk radikal bebas sangat reaktif yang dapat menimbulkan kerusakan pada membran sel, protein, dan deoxyribonucleic acid (DNA), sehingga menyebabkan gangguan produksi insulin oleh sel beta langerhans pankreas (Wilson, 1988). Szkudelski (2001) menyatakan bahwa streptozotocin memasuki sel beta langerhans pankreas melalui glucose transporter 2 (GLUT 2) dan menyebabkan alkilasi. Hal ini didahului oleh pembatasan pembentukan adenosin trifosfat pada mitokondria akibat pembentukan radikal bebas, peningkatan enzim xanthine oxidase dan penghambatan siklus Krebs. Terdapat dua tipe diabetes mellitus akibat induksi streptozotocin (STZ), yaitu diabetes mellitus tipe 1 dan diabetes mellitus tipe 2 (Yaturu, 2011). Penelitian ini dimaksudkan untuk membuat kondisi diabetik eksperimental pada hewan coba tikus putih (Rattus norvegicus) jantan dengan penggunaan agen diabetagonik streptozotocin. 


\section{METODE PENELITIAN}

\section{Induksi STZ untuk Diabetes Mellitus}

Tikus yang digunakan dalam penelitian ini tikus putih (Rattus novergicus), jenis kelamin jantan, umur dua bulan. Rataan berat badan $200 \mathrm{~g}$, sebanyak 88 ekor. Tikus diadaptasikan selama 2 minggu. Diberi makan pelet ABS2 5-10 g/hari dan air minum secara ad libitum. Tikus dipuasakan terlebih dahulu selama 12 jam sebelum induksi STZ. Streptozotocin dilarutkan dalam 0.01M buffer sitrat, $\mathrm{pH} 4,5$ dan selalu disiapkan dalam kondisi fresh untuk penggunaan dalam waktu 10-15 menit. Injeksi STZ diberikan secara intraperitoneal dan dosis ditentukan berdasarkan berat badan tikus. Dosis STZ yang diberikan 45 $\mathrm{mg} / \mathrm{kg}$ BB (Nurdiana, 1998). Injeksi STZ dilakukan hanya sekali untuk menginduksi diabetes mellitus.

\section{Pemberian Perlakuan dan Pengamatan}

Pada awal percobaan, kadar glukosa darah tikus diukur dengan menggunakan glukometer dengan cara ujung ekor tikus dipotong $1 \mathrm{~mm}$ menggunakan gunting, lalu darah tikus disentuhkan pada stick glukometer dan dicatat angka yang muncul pada layar glukometer. Pengamatan glukosa darah dilakukan pada hari ke-0 dan hari ke-3 pasca induksi STZ. Pada hari tersebut diamati persentase kondisi terjadinya diabetik pada tikus. Kondisi diabetik normal adalah 75-150 $\mathrm{mg} / \mathrm{dl}$, diabetik ringan 150-200 mg/dL sedang 200$400 \mathrm{mg} / \mathrm{dLdan}$ kondisi diabetik berat di atas $400 \mathrm{mg} / \mathrm{dL}$ (Lenzen et al., 1996).

\section{Pemeriksaan Kadar Glukosa Darah}

Pemeriksaan kadar glukosa darah menggunakan metode enzimatik, mengunakan alat Gluko-Dr® bereaksi secara spesifik dengan glukosa yang terdapat di dalam darah. Molekul glukosa yang dioksidasi oleh enzim Glukose Oksidase (GOD) menghasilkan elektron yang ditangkap oleh elektroda sehingga kadar glukosa berbanding lurus dengan sinyal elektronik yang diterima. Jumlah darah yang dibutuhkan untuk mengukur kadar glukosa darah adalah 2,5-4,0 $\mathrm{L}$, darah diletakkan pada sisi kanan test strip, darah akan terserap secara otomatis dan hasil pengukuran akan terbaca setelah sebelas detik pada Gluko-Dr test Meter. Kadar glukosa darah diukur dalam satuan $\mathrm{mg} / \mathrm{dL}$.

\section{Analisis Data}

Data yang diperoleh dianalisis secara deskriptif. Data didapatkan berdasarkan persentase kenaikan kadar glukosa darah pada tikus putih jantan. Persentase tikus yang meningkat kadar glukosa darah didapat dengan rumus:

$\%=\frac{\text { Jml tikus hiperglikemia }}{\text { Jml tikus yang diinduksi STZ }} \times 100 \%$

\section{HASIL DAN PEMBAHASAN}

Pada penghitungan hasil dari 88 ekor tikus putih jantan yang dilakukan pengamatan di hari ke-0 sebelum induksi agen streptozotocin didapatkan sebanyak 82 ekor $(93,2 \%)$ tikus putih jantan dalam kondisi normal $(75-150 \mathrm{mg} / \mathrm{dL}$ dan 6 ekor $(6,8 \%)$ tikus mengalami kondisi diabetik ringan yang kadar diabetiknya berkisar antara 150-200 mg/dL. Tikus ini diadaptasi lagi sehari dan diukur ulang kadar glukosa darah, didapatkan kadar glukosa yang normal. Pada hari ke-3 penghitungan hasil pengamatan didapatkan hasil yaitu 40 ekor tikus $(45,2 \%)$ dalam kondisi normal, 19 ekor tikus $(21,5 \%)$ dalam kondisi diabetik ringan, 10 ekor tikus $(11,8 \%)$ dalam kondisi diabetik sedang dan terdapat 19 ekor tikus $(21,5 \%)$ yang mengalami kondisi diabetik berat. Total jumlah tikus putih yang mengalami diabetes adalah sebanyak 48 ekor tikus atau sebesar 54,8\% (Gambar 1).

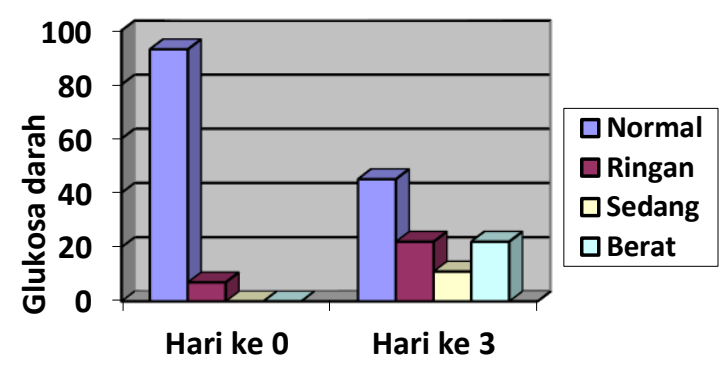

Gambar 1. Persentase kadar glukosa darah. 
Hasil ini menujukkan bahwa pada hari ke-0, kadar glukosa darah awal tikus putih (Rattus norvegicus) jantan masih dalam batas normal dan belum mengalami peningkatan glukosa darah yang terlihat secara langsung. Pada hari ke-3 terjadi adanya peningkatan glukosa darah secara cepat akibat induksi agen streptozotocin. Pada hari ke 0 atau hari kontrol sebelum dilakukan induksi STZ pada hewan coba tikus putih (Rattus norvegicus) jantan yang berjumlah 88 ekor tikus dilakukan pemeriksaan kadar glukosa darah yang ternyata terdapat sekitar $6,8 \%$ atau 6 ekor tikus yang mengalami peningkatan kadar glukosa darah bersifat ringan. Hal ini bisa diakibatkan oleh beberapa faktor atau kondisi seperti stres sehabis makan dan peningkatan aktivitas (Nugroho, 2006). Setelah diadaptasi lebih lama kadar glukosa darah kembali normal.

$\begin{array}{ccc}\text { Kondisi } & \text { stres } \quad \text { pada } & \text { tikus } \\ \text { mengakibatkan } & \text { gangguan } & \text { pada }\end{array}$
pengontrolan kadar gula darah yang dilakukan oleh hormon sehingga tubuh akan memproduksi hormon epinefrin dan kortisol yang menyebabkan kadar gula darah meningkat secara otomatis (Stumvoll, et al., 2005). Pada kondisi setelah makan kadar gula darah dapat meningkat karena adanya gula yang masuk melalui asupan makanan, gula yang masuk di dalam tubuh akan terkombinasi dalam hemoglobin dan akan diubah menjadi energi sehingga dapat digunakan oleh sel-sel dan jaringan tubuh. Faktor lain yang dapat mempengaruhi peningkatan kadar glukosa darah yaitu aktifitas yang meningkat. Aktifitas fisik dapat mengontrol gula darah. Glukosa akan diubah menjadi energi pada saat beraktifitas fisik. Aktifitas fisik mengakibatkan insulin semakin meningkat sehingga kadar gula dalam darah akan berkurang. Pada tikus yang jarang bergerak, zat makanan yang masuk ke dalam tubuh tidak dibakar tetapi ditimbun dalam tubuh sebagai lemak dan gula (Richardo et al., 2014).

Beberapa kondisi yang umumnya memudahkan tikus untuk beradaptasi adalah suhu lingkungan, derajat keasaman
$(\mathrm{pH})$, kadar oksigen dan kondisi pakan. Jangka waktu adaptasi masing-masing tikus bervariasi, tergantung ekstrimnya perbedaan kondisi lingkungan asal tikus (tempat breeder) dipelihara dengan lingkungan di laboratorium. Perbedaan komposisi nutrisi pakan yang diberikan (Satya, 2011). Untuk memimalisir perbedaan tersebut diperlukan informasi dasar dari pakan, dan kondisi lingkungan di tempat pembiakan. Selama pemeliharaan hendaknya kondisi hewan harus dalam keadaan nyaman (tidak stres). Pada kondisi stres terjadi peningkatan kadar kolestrol dan glukosa dalam tubuh. Hal tersebut akan meningkatkan detak jantung. Kondisi itu dapat menyebabkan hasil yang tidak valid berkaitan dengan pengukuran kolesterol dan detak jantung (Hadisaputro et al., 2007).

Pada hari ke-3 pasca induksi STZ, didapatkan hasil kadar glukosa darah tikus putih (Rattus norvegicus) jantan dalam kondisi diabetik dengan derajat yang berbeda yaitu normal, ringan, sedang dan berat. Hal ini dapat terjadi karena konsentrasi glukosa dalam darah ditentukan oleh keseimbangan proses-proses antara lain: penyerapan glukosa dari saluran pencernaan, transportasi glukosa ke dalam sel, pembentukan glukosa oleh sel (terutama di hati) dan eksresi glukosa oleh urin tikus yang juga berbeda-beda (Auroma et al, 2006).

Beberapa faktor yang menyebabkan terjadinya kondisi diabetik ringan, sedang dan berat didasarkan pada kondisi genetik dan internal hewan. Hal ini mengacu pada mekanisme kerja reseptor dari induksi agen streptozotocin yang berbeda di dalam tubuh tiap individu tikus tersebut. Pada kondisi diabetik ringan terdapat faktor yang berhubungan erat dengan kondisi genetik hewan dan kondisi internal hewan yang stabil sehingga mekanisme kerja reseptor berjalan lambat untuk merusak fungsi sel $\beta$ pankreas (Kendran et al., 2013). Kondisi diabetik sedang mengasumsikan terjadinya kerusakan DNA yang lebih cepat, STZ mendonorkan NO (nitric oxide) yang 
mempunyai kontribusi terhadap kerusakan sel melalui peningkatan aktivitas dan pelepasan radikal bebas. Nitric oxide dihasilkan sewaktu STZ mengalami metabolisme dalam sel. Selain itu, STZ juga mampu membangkitkan oksigen reaktif yang mempunyai peran tinggi dalam kerusakan sel $\beta$ pankreas (Jonhson, 1998). Pada kondisi diabetik berat kerusakan DNA akibat STZ dapat mengaktivasi poli ADPribosilasi yang kemudian mengakibatkan penekanan NAD+ seluler dengan sempurna, selanjutnya menyebabkan penurunan jumlah ATP dan akhirnya terjadi penghambatan sekresi dan sintesis insulin. Selain itu, kemungkinan dapat menginduksi terjadinya nekrosis (Akpan et al., 1987; Szkudelski, 2001).

Tabel 1. Rataan kadar gluosa darah (mg/dl)

\begin{tabular}{lcc}
\hline $\begin{array}{l}\text { Kadar } \\
\text { Diabetik }\end{array}$ & Hari Ke-0 & Hari ke-3 \\
\hline Normal & $110 \pm 4,3$ & $115 \pm 4,4$ \\
Ringan & $155 \pm 5,1$ & $170 \pm 5,3$ \\
Sedang & 0 & $315 \pm 7,3$ \\
Berat & 0 & $410 \pm 8,4$ \\
\hline
\end{tabular}

Keterangan: Nilai rataan dicari berdasarkan rumus standar deviasi (SD) dengan hasil nilai rata-rata $\pm \mathrm{SD}$.

Rataan kadar glukosa darah hari ke-0 pada 82 ekor tikus putih yaitu $110 \pm 4,3$ mg/dL sedangkan 6 ekor tikus mengalami kondisi dibetik ringan dengan rata-rata kadar diabetik yaitu $155 \pm 5,1 \mathrm{mg} / \mathrm{dL}$. Pada hari ke 3 terdapat 40 ekor tikus dalam keadaan normal dengan nilai rata-rata kadar diabetik sebesar $115 \pm 4,4 \mathrm{mg} / \mathrm{dL}$ sebanyak 19 ekor tikus dengan kondisi kadar diabetik ringan dengan kadar 170 $\pm 5,3 \mathrm{mg} / \mathrm{dL}$ sebanyak 10 ekor tikus dengan kondisi diabetik sedang dengan kadar 315 $\pm 7,3$ mg/dLdan sebanyak 19 ekor tikus dengan kondisi rata-rata diabetik berat yaitu dengan kadar 410 $\pm 8,4 \mathrm{mg} / \mathrm{dL}$.

Secara keseluruhan peningkatan kadar glukosa darah pada tikus putih jantan ini disebabkan oleh terganggunya sel $\beta$ pada kelenjar pankreas oleh agen streptozotocin. Mekanisme aksi yang menimbulkan perusakan yang selektif oleh STZ diketahui dengan jelas. Streptozotocin berikatan dengan GLUT-2 yang memfasilitasi masuknya STZ ke dalam sitoplasma sel $\beta$ pankreas, meningkatkan depolarisasi pada mitokondria sebagai akibat pemasukan ion $\mathrm{Ca} 2+$ yang diikuti oleh penggunaan energi berlebih sehingga terjadi kekurangan energi di dalam sel. Mekanisme ini menyebabkan produksi insulin terganggu sehingga terjadi defisiensi insulin yang menyebabkan seluruh glukosa yang dikonsumsi oleh tubuh tidak dapat diproses secara sempurna, akibatnya kadar glukosa dalam tubuh meningkat (Greenspan, 1998).

\section{SIMPULAN DAN SARAN}

\section{Simpulan}

Pemberian STZ dapat menimbulkan kondisi hiperglikemia diabetik ekperimental dalam waktu 3 hari.

\section{Saran}

Streptozotocin dapat digunakan sebagai agen untuk membuat kondisi diabetik eksperimental pada tikus. Pada penyiapan hewan model tikus sebagai model hewan diabetik diperlukan jumlah tikus awal yang lebih banyak.

\section{UCAPAN TERIMAKASIH}

Penulis mengucapkan terima kasih kepada Direktorat Penelitian dan Pengabdian kepada Masyarakat, Direktorat Jendral Pendidikan dan Kebudayaan Republik Indonesia atas bantuan dana penelitian melalui Lembaga Penelitian dan Pengabdian Masyarakat Universitas Udayana (LPPM- UNUD), dengan kontrak No: 104.18/UN 14.2/PNL.01.03.00/2014.

\section{DAFTAR PUSTAKA}

Akpan JO, Wright PH, Dulin WE. 1987, A comparison of the effects of streptozotocin, N-methylnitrosourea and alloxan on isolated islets of Langerhans. Diabetes \& Metabolism. 13(2): 122-128.

Alwan AAS. 1994. Management of Diabetes Mellitus Standards of Care and Clinical Practice Guidelines. In Draf J. Med. 19(4). 
Auroma OI, Neergheen VS, Bahorun T, Jen LS. 2006. Free radical, antioxidants and diabetes: embryopathy, retinopathy, neuropathy, nephropathy and cardiovascular complications. J. Neuroembryol Aging. 4: 117-137.

Greenspan FS.1998. Endokrinologi Dasar dan Klinik, Ed. 4, Penerbit Buku Kedokteran, EGC, Jakarta. Pp: 775.

Hadisaputro S., Setyawan H. 2007. Epidemiologi dan Faktor-Faktor Risiko terjadiDiabetes Mellitus tipe 2. Dalam: Darmono, dkk, editors. Naskah Lengkap Diabetes mellitus Ditinjau dari Berbagai Aspek Penyakit dalam dalam rangka Purna Tugas Prof Dr. dr. RJ Djokomoeljanto. Badan Penerbit Universitas Diponegoro Semarang. Pp.133-153.

Jonhson M. 1998. Diabetes Therapy dan Pencegahannya, Jawa Barat: ISBN 979 - 504-110 X.

Kendran AAS, Sudisma IGN, Sulabda IN, Gorda IW, Dewi L, Loudi BM. 2013. Kadar Glukosa Darah Anjing Kintamani. Bul.Vet. Udayana. 5(2): 7986.

Lenzen S. 2008. The mechanism of alloxan and streptozotocin incuded diabetes. $J$. Med. Draf. 11: YN1123.2.

Nugroho AE. 2006. Review Hewan Percobaan Diabetes Mellitus: Patologi Dan Mekanisme Aksi Diabetogenik. Fakultas Farmasi Universitas Gadjah Mada.

Nurdiana N. 1998. Efek streptozotocin sebagai bahan diabetogenik pada tikus wistar dengan cara intraperitonial dan intravena. Majalah Kedokteran Unibraw. 14(2): 66-77.

Richardo B, Pengemanan D, Majuli N. 2014. Analisis Faktor Resiko Penyebab Terjadinya Diabetes Mellitus Tipe 2 pada Wanita Usia Produktif di Puskesmas Wawunasa. Jurnal eBiomedik. 2(2): 404-412.
Satya BMN. 2011. Manajemen Hewan Coba Tikus Putih dan Mencit. Evaluasi Gizi. Fakultas Teknologi dan Pangan.

Stumvoll M, Goldstein BJ, vanHaeften TW. 2005. Type 2 diabetes: principles of pathogenesis and therapy. Lancet. 365 : $1333-1346$.

Suyono S. 2005. Patofisiologi Diabetes Mellitus dalam Penatalaksanaan Diabetes Mellitus Terpadu: Pusat Diabetes dan Lipid RSUP Nasional Dr. Cipto Mangunkusumo. Fakultas Kedokteran Universitas Indonesia. Jakarta.

Szkudelski T. 2001. The Mechanism of alloxan and streptozotocin action in $\mathrm{B}$ cells of therat pancreas. Physio. Res. 50(6): 537-546.

World Health Organisation. 2003. Deffinition, Diagnosis and Classification of Diabetes Mellitus and its Complications. Report of a WHO Consultation. Geneva-Switzerland. S536.

Wilson GL. 1988. Mechanism of nitroroure induced beta cell damage. activation of poly (adp-ribose) syntase and cellular distribution. Diabetes. 37: 213-216.

Yaturu S. 2011. Obesity and type 2 diabetes. J. Diabetes Mellitus.1(4):10-6.

Yuda IKA, Anthara MS, Dharmayudha AAGO. 2013. Identifikasi Golongan Senyawa Kimia Estrak Etanol Buah Pare (Momordica charantia) dan Pengaruhnya Terhadap Penurunan Kadar Glukosa Darah Tikus Putih Jantan (Rattus novergicus) yang Diinduksi Aloksan. Bul.Vet. Udayana. 5(2): 87-95.

Yuliantika NMR, Gelgel KTP, Kardena IM. 2013. Efek Toksisitas Ekstrak Daun Sirih Merah Terhadap Gambaran Mikroskopis Ginjal Tikus Putih Diabetik Yang Diinduksi Aloksan. Bul.Vet. Udayana. 5(2): 114-121. 